\title{
Pengembangan Android Apps Berbasis Discovery Learning untuk Meningkatkan Pemahaman Konsep Matematis Siswa Kelas VII
}

\author{
Lilik Ariyanto $^{1, a)}$, Derisna Aditya $\mathrm{P}^{\text {,b) }}$, Ida Dwijayanti ${ }^{3, \mathrm{c})}$ \\ ${ }^{1,2,3}$ Program Studi Pendidikan Matematika, Universitas PGRI Semarang \\ a) lilikariyanto@upgris.ac.id \\ b ) aditya.derisna@gmail.com \\ c)idadyana@gmail.com
}

\begin{abstract}
Lack of innovative learning media that is interesting, practical and easy to use in learning such as listening to lesson modules or seeing powerpoint shows used by teachers, thus causing learning to be ineffective, unattractive, and slow to understand, this results in a lack of understanding of mathematical concepts. Because of this, researchers are trying to develop an interesting and interactive learning media.This type of research is a development research that aims to produce learning media on Android based discovery learning apps that are feasible to use and to improve understanding of mathematical concepts of students class vii. The method used is ADDIE method. Which consists of 5 stages, namely Analysis, Design, Development, Implementation and Evaluation. Data analysis was carried out by normality, homogeneity, n-gain test, and right-sided t test. The results of this study can be concluded that (1) the results of the percentage of media expert validation amounted to $80.26 \%$, material experts $86.36 \%$ and student response responses of $87.16 \%$ with the criteria of each very good. (2) the results of the n-gain test obtained that there is an increase in understanding of mathematical concepts of students who use learning media on Android based discovery learning applications. (3) data from the field shows that student learning outcomes that obtain learning media android apps based on discovery learning are better than students who use conventional learning.
\end{abstract}

Keywords: Development, Technolgy Learning System, Android Apps, Discovery Learning, Understanding of mathematical concepts

\begin{abstract}
Abstrak. Kurangnya inovasi media pembelajaran yang menarik, praktis dan mudah digunakan dalam pembelajaran seperti menyimak modul pelajaran atau melihat tayangan powerpoint yang digunakan oleh guru, sehingga menyebabkan pembelajaran kurang efektif, tidak menarik, dan lambat untuk dimengerti, hal ini mengakibatkan kurangnya pemhaman konsep matematis. Karena hal tersebut, peneliti mengupayakan dengan mengembangkan suatu media pembelajaran menarik dan interaktif. Jenis penelitian ini merupakan penelitian pengembangan yang bertujuan untuk menghasilkan media pembelajaran android apps berbasis discovery learning yang layak digunakan dan untuk meningkatkan pemahaman konsep matematis siswa kelas vii. Metode yang digunakan yaitu metode ADDIE. Yang terdiri dari 5 tahap yaitu Analysis (Analisis), Design (Perancangan), Development (Pengembangan), Implementation (Implementasi) dan Evaluation (Evaluasi). Analisis data dilakukan dengan uji normalitas, homogenitas, uji n-gain, dan uji t pihak kanan. Hasil dari penelitian ini dapat disimpulkan bahwa (1) hasil presentase validasi ahli media sebesar $80,26 \%$, ahli materi $86,36 \%$ dan respon tanggapan siswa sebesar 87,16\% dengan kriteria masing-masing sangat baik. (2) hasil uji n-gain diperoleh bahwa terdapat peningkatan pemahaman konsep matematis siswa yang menggunakan media pembelajaran android apps berbasis discovery learning. (3) data dari lapangan menunjukkan bahwa hasil belajar siswa yang memperoleh media pembelajaran android apps berbasis discovery learning lebih baik dibandingkan dengan siswa yang menggunakan pembelajaran konvensional.
\end{abstract}

Kata kunci: Pengembangan, Android, Android Apps, Discovery Learning, Pemahaman Konsep.

\section{PENDAHULUAN}

Pendidikan memiliki peranan penting guna mempersiapkan sumber daya manusia yang berkualitas dan mampu berkompetensi dalam perkembangan ilmu pengetahuan dan teknologi, sehingga pendidikan harus dilaksanakan dengan sebaik-baiknya untuk 
memperoleh hasil yang maksimal. Perkembangan ilmu pengetahuan dan teknologi dalam dunia pendidikan semakin berkembang, sehingga manusia dituntut mengikuti pembaharuan-pembaharuan untuk mengimbangi perkembangan tersebut. Perkembangan teknologi informasi dalam dunia pendidikan, merupakan salah satu kemajuan teknologi yang bisa diterapkan dan dijadikan acuan dalam mengembangkan pengetahuan. Pendapat ini didukung oleh Putra (2013: 126) yang menyatakan bahwa teknologi informasi (TIK) berkembang dan menjadi bagian yang tidak dapat dipisahkan dari kehidupan manusia, peran teknologi informasi sudah merambah ke segala bidang kehidupan, terlebih lagi dalam bidang pendidikan.

Selain itu, pendidikan di Indonesia juga harus bisa mengalami peningkatan mutu pendidikan yang memiliki daya saing di tingkat nasional dan internasional. UndangUndang Republik Indonesia Nomor 20 Tahun 2003 tentang Sistem Pendidikan Nasional. Pendidikan adalah usaha sadar dan terencana untuk mewujudkan suasanan belajar dan proses pembelajaran agar siswa secara aktif mengembangkan potensi dirinya untuk memiliki kekuatan spiritual keagamaan, pengendalian diri, kepribadian, kecerdasan, akhlak mulia, serta keterampilan yang diperlukan dirinya, masyarakat, bangsa, dan Negara. Undang-undang tersebut merupakan dasar hukum penyelenggarakan sistem pendidikan nasional, di mana memuat visi, misi, fungsi, dan tujuan pendidikan nasional, serta strategi pembangunan pendidikan nasional.

Sementara itu Verowita, dkk. (2012: 49) menjelaskan bahwa kemampuan pemahaman konsep matematis merupakan salah satu penentu dari tujuan pembelajaran matematika. Hal ini juga senada dengan Wardani (2008: 8) bahwa memahami konsep matematika merupakan salah satu tujuan dari mata pelajaran matematika di sekolah. Jadi tujuan tercapainya pendidikan di Indonesia dalam pembelajaran matematika adalah salah satunya dengan tercapainya pemahaman konsep matematis siswa dalam pembelajaran mata pelajaran matematika.

Konsep adalah salah satu aspek terpenting dalam pembelajaran matematika, hal ini dijelaskan oleh Ariati (2016: 106) yang menyatakan bahwa terdapat tiga elemen dalam mempelajari matematika diantaranya, yaitu ketrampilan, konsep, dan pemecahan masalah. Jika diibaratkan konsep-konsep merupakan batu-batu pembangunan dalam berpikir (Murizal dkk, 2012: 19). Pentingnya pemahaman konsep matematika terlihat dalam tujuan pertama pembelajaran matematika menurut Depdiknas (dalam Linuhung \& Satrio, 2016: 52) yaitu memahami konsep matematika, menjelaskan keterkaitan antar konsep dan mengaplikasikan konsep atau algoritma secara luwes, akurat, efisien dan tepat dalam pemecahan masalah. Oleh karena itu, kemampuan pemahaman konsep matematis adalah salah satu tujuan penting dalam pembelajaran matematika.

Kurangnya kemampuan pemahaman konsep matematis merupakan salah satu penyebab siswa kurang dalam menyelesaikan masalah suatu matematis. Berdasarkan observasi awal pada salah satu SMP N di Kota Semarang, hal ini dikarenakan kurangnya inovasi media pembelajaran yang menarik, praktis dan mudah digunakan dalam pembelajaran. Kebanyakan siswa hanya menyimak buku pelajaran atau menggunakan 
powerpoint yang digunakan oleh guru. Karena hal tersebut, menyebabkan pembelajaran kurang efektif, tidak menarik, dan lambat untuk dimengerti, hal tersebut berdampak pada tingkat pemahaman konsep matematis siswa. Hasil lain dengan melakukan wawancara, menyatakan bahwa pemahaman konsep siswa terhadap materi pembelajaran matematika bisa dikatakan masih rendah, dikarenakan pada saat pembelajaran berlangsung banyak siswa yang kurang aktif dalam pembelajaran berlangsung, terdapat siswa yang malu untuk bertanya, kondisi yang kaku ataupun tidak kondusif didalam kelas saat pembelajaran dan banyaknya siswa yang hasil belajarnya belum mencapai KKM (Kriteria Ketuntasan Minimal) yang ditentukan saat ulangan. Hal ini ditunjukan dengan adanya data Pusat Penilaian Pendidikan (Badan Penelitian dan Pengembangan Kementrian Pendidikan dan Kebudayaan) yang menyatakan bahwa rerata Ujian Nasional Berbasis Komputer pada mata pelajaran matematika tahun 2017 di salah satu SMP Kota Semarang adalah 55.76 dan persentase daya serap siswa berdasarkan materi pada Ujian Nasional tahun 2014/2015 pada materi bangun geometri lebih rendah dibandingkan materi yang lain yaitu $47.59 \%$. Pemahaman konsep matematis siswa sangatlah penting bagi siswa kelas VII, dikarenakan pada materi yang ada pada keas VIII dan IX terdapat materi awal dari kelas VII. Jika pemahaman konsep matematis siswa pada kelas VII rendah, maka akan kesulitan untuk memahami konsep matematis pada kelas VIII dan kelas IX bahkan pada saat ujian akhir semester ataupun Ujian Nasional akan merasakan kesulitan karena rendahnya pemahaman konsep matematis.

Masalah-masalah yang berkaitan dengan rendahnya pemahaman konsep matematis, dapat diupayakan dengan cara menggunakan media pembelajaran yang menarik dan interaktif agar dapat digunakan dalam pembelajaran matematika sehingga siswa dapat tertarik dan termotivasi dalam proses pembelajaran untuk meningkatkan pemahaman konsep matematis. Pengembangan media pembelajaranyang digunakan dalam penelitian ini yaitu berdasarkan model pengembangan ADDIE yang dikembangkan oleh Branch. Berdasarkan model pengembangan ADDIE bahwa dalam pengembangan suatu produk harus melewati lima fase atau lima tahapan yang sistematik (Pribadi, 2009: 128). Lima tahap tersebut adalah Analysis, Design, Development, Implementation dan Evaluation. Menurut Walker \& Heres (dalam Arsyad, 2014: 219-220) memberikan kriteria dalam mereview perangkat lunak media pembelajaran yang berdasarkan kepada kualitas. Kualitas yang dimaksutkan adalah kualitas isi dan tujuan, kualitas instruksional dan kualitas teknis. Dalam hal ini menunjukan bahwa dalam mengembangkan media pembelajaran juga diliat kriteria untuk perangkat lunak media pembelajaran, agar media pembelajaran yang dipakai bisa praktis dan efisien saat digunakan.

Salah satu media yang digunakan adalah media pembelajaran Mobile learning. Mobile learning merupakan media pembelajaran yang menggunakan media Mobile. Media Mobile yang dimaksud adalah Smartphone yang berbasis Andorid. Mobile learning yang digunakan untuk media pembelajaran adalah Aplikasi Android atau dalam bahasa asingnya yaitu Android Apps. Menurut Mehdipour (2013: 93) mobile learning memiliki suatu fitur dan fungsi untuk mendukung siswa. Dengan kata lain mobile learning merupakan pembelajaran yang memanfaatkan mobile sebagai media belajar dapat dilaksanakan 
dimanapun dan kapanpun sehingga pembelajararan dapat berlangsung efektif. Mobile learning merupakan salah satu alternatif untuk mengembangkan suatu media pembelajaran.

Berdasarkan penelitan yang dilakukan oleh Su et all (2015) menyatakan bahwa Teknologi mobile dan gamification menjadi proses pembelajaran botani yang bisa mencapai kinerja belajar yang lebih baik dan tingkat motivasi yang lebih tinggi daripada pengajaran yang tradisional. Hal itu juga sejalan dengan Nasution (2016), yang menyatakan bahwa strategi pembelajaran berbasis mobile learning lebih interaktif, menyenangkan, serta sangat efektif untuk mencapai tujuan pembelajaran. Hal ini ditunjukan dengan hasil penelitian menurut Gharini (2015), perangkat mobile learning memenuhi aspek valid, praktis, serta efektif yang ditunjukkan oleh angket respon siswa serta tes hasil belajar siswa dengan rata-rata prosentase $96,33 \%$ dalam peneliannya di SMP N 1 Mojokerto pada materi peluang.

Untuk mengatasi permasalahan kurangnya pemahaman konsep di sekolah, tidak hanya dengan menggunakan media pembelajaran saja, tetapi juga harus didukung oleh model pembelajaran yang tepat dan dapat memberikan kepada siswa untuk memperoleh atau membangun pengetahuannya sendiri dengan cara menemukan suatu konsep yang dipelajarinya. Model yang digunakan agar siswa dapat menemukan suatu konsep yang dipelajarinya yaitu dengan menggunakan model pembelajaran Discovery Learning (Model Penemuan). Karim (2011: 23) berpendapat bahwa model penemuan merupakan cara untuk menyampaikan ide/gagasan dengan proses menemukan, dalam proses ini siswa berusaha menemukan konsep, rumus dan semacamnya dengan bimbingan guru. Kelebihan penerapan Discovery Learning adalah a) dapat membantu siswa untuk memperkuat pemahaman konsep matematis, b) pembelajaran berpusat pada siswa sehingga guru dan siswa berperan sama-sama aktif mengeluarkan gagasan-gagasan, serta c) memungkinkan siswa berkembang dengan cepat sesuai dengan kecepatannya sendiri. Dalam menerapkan Model penemuan (Discovery Learning) diharapkan seorang guru bertindak sebagai pembimbing dan fasilitator agar dapat meningkatkan peran aktif siswa dalam pembelajaran sehingga dapat meningkatkan pemahaman konsep matematis.

Berdasarkan uraian tersebut, penelitian ini bertujuan untuk: (a) Mengembangkan perangkat pembelajaran menggunakan Android Apps, yaitu Adobe Flash CS 6 berbasis Discovery Learning yang valid sebagai media pembelajaran matematika yang menarik, (b) Untuk mengetahui adanya peningkatan kemampuan pemahaman konsep matematis siswa setelah menggunakan media pembelajaran Android Apps berbasis Discovery Learning berdasarkan faktor keseluruhan siswa, (c) Untuk mengetahui kemampuan pemahaman konsep matematis pada siswa SMP kelas VII setelah mendapatkan pembelajaran menggunakan media pembelajaran Android Apps berbasis Discovery Learning lebih baik dari pada kemampuan pembelajaran konvensional berdasarkan keseluruhan siswa.

\section{METODE}

Populasi adalah adalah wilayah generalisasi yang terdiri atas obyek atau subyek yang mempunyai kualitas dan karakteristik tertentu yang ditetapkan oleh peneliti untuk dipelajari dan kemudian ditarik kesimpulannya (Sugiyono, 2014: 80). Populasi dalam penelitian ini adalah siswa kelas VIII SMP Negeri 40 Semarang Tahun ajaran 2017/2018. Sampel adalah sebagian dari populasi itu (Sugiyono, 2014: 81). Sampel dalam penelitian ini adalah kelas VII-H sebagai kelas 
eksperimen dan kelas VIII-F sebagai kelas kontrol. Penelitian ini dilaksanakan dari 26 April 2018 sampai 28 Mei 2018.

Jenis penelitian yang dilakukan adalah penelitian dan pengembangan (Reseacrh and Development) model ADDIE, yaitu tahap Analysis (Analisis), Design (Perancangan), Development (Pengembangan), Implementation (Implementasi), Evaluation (Evaluasi), serta desain penelitian menggunakan One Group Pretest-Posttest. Tahap analysis terdidi dari dua tahap, yaitu analisis kinerja dan analisis kebutuhan. Tahap Design dilakukan untuk menyiapkan dan merancang perangkat dengan menyusun : silabus yang mengacu pada kurikulum K-13, RPP, insrumen penelitian, serta mendesain desain awal media android apps berbasis dsicovery learning. Tahap Development ini dilakukan validasi produk oleh validator. Sugiyono (2015: 414) validasi ahli dapat dilakukan dengan cara menghadirkan beberapa pakar atau tenaga ahli yang sudah berpengalaman untuk menilai produk baru yang dirancang tersebut. Dalam penelitian ini terdapat 2 kategori yang di validasi meliputi validasi ahli media dan validasi ahli materi. Tahap implementation, sebelum peneliti menerapkan pembelajaran dengan media pembelajaran Android Apps berbasis Discovery Learning, peneliti melakukan uji coba soal terlebih dahulu pada kelas ujicoba, hal ini bertujuan dari hasil soal ujicoba tersebut akan dicari validitas, reliabilitas, taraf kesukaran dan daya pembeda dari 14 soal menjadi 7 soal yang akan digunakan untuk pretest sebelum penelitian dimulai dan posttest sesudah penelitian dilakukan. Setelah melakukan ujicoba soal dan mengetahui soal yang digunakan untuk pretest dan posttesti, peneliti melakukan tes awal berupa pre test, kemudian mengimplementasikan atau menerapkan rancangan media yang telah dikembangkan pada situasi nyata yaitu kelas eksperimen. Peneliti membimbing siswa untuk mencapai tujuan belajar dan solusi untuk mengatasi kesenjangan hasil belajar. Tahap evaluation peneliti melakukan tes akhir berupa post test pada pertemuan terakhir untuk mengetahui hasil belajar siswa setelah melaksanakan pembelajaran menggunakan media berbasis android. Serta melakukan evaluasi melalui angket respon tanggapan siswa terhadap produk media pembelajaran android apps berbasis discovery learning yang telah diterapkan terhadap kelas eksperimen.

Produk akan dinilai dari dua hal yaitu kevalidan dan kepraktisan. Instrumen penilaian kevalidan meliputi lembar validasi aplikasi android. Instrumen kepraktisan menggunakan angket respon tanggapan siswa terhadap produk media pembelajaran android apps berbasis discovery learning. Lembar kevalidan dan kepraktisan menggunakan rentang skala 5 penilaian yaitu Sangat setuju, setuju, tidak berpendapat, tidak setuju dan sangat tidak setuju. Data tersebut dikonversikan menjadi data kualitatif dengan menggunakan kriteria sebagai berikut :

Tabel 1. Range Presentase dan Kriteria Kuantitatif Program

\begin{tabular}{ccc}
\hline No & Interval & Kriteria \\
\hline 1 & $81 \%-100 \%$ & Sangat baik \\
2 & $61 \%-80 \%$ & Baik \\
3 & $41 \%-60 \%$ & Cukup \\
4 & $21 \%-40 \%$ & Kurang \\
5 & $0 \%-20 \%$ & Kurang sekali
\end{tabular}

Kemudian untuk analisis data keefektifan dilakukan dengan 2 tahap, yaitu analisis data awal dan data akhir. Data awal dilakukan dengan cara mencari Uji normalitas, Uji Homogenitas dan Uji Kesamaan Rata-rata (Uji t Dua Pihak) untuk kelas kontrol dan eksperimen. Data akhir dilakukan dengan cara mencari Uji Normalitas, Uji Homogenitas, Uji N-Gain dan Uji t Pihak Kanan untuk kelas kontrol dan kelas eksperimen. 


\section{HASIL DAN PEMBAHASAN}

Jenis penelitian ini adalah Research and Development (R\&D) yang berorientasi pada produk. Pengembangan media pembelajaran android apps berbasis dsicovery learning pada materi segiempat menggunakan model ADDIE, yang terdiri atas 5 tahap utama yaitu: (1) Analysis (analisis); (2) Design (perancangan); (3) Development (pengembangan); (4) Implementation (implementasi); (5) Evaluation (evaluasi)

Tahap pertama analysis (analisis), Tahap ini digunakan untuk memperoleh informasi mengenai kebutuhan atau masalah yang melatarbelakangi dikembangkannya media pembelajaran android apps berbasis discovery learning untuk meningkatkan pemahaman konsep matematis. Peneliti melakukan melakukan observasi dan wawancara langsung dengan salah satu guru matematika di SMP N 40 Semarang. Dari hasil wawancara diperoleh informasi bahwa dalam proses pembelajaran penggunaan media pembelajaran yang masih terbatas pada buku, modul, dan power point. Media powerpoint yang digunakan kurang menarik perhatian dan minat siswa karena hanya membahas materi secara umum dan kurang adanya visualisasi animasi yang mendukung. Gagne (dalam Mahnun, 2012:28) menyatakan bahwa media adalah berbagai jenis komponen dalam lingkungan siswa yang dapat merangsangnya untuk belajar. Maka dari itu pengembangan media pembelajaran sangat diperlukan untuk merangsang siswa untuk belajar.

Dari permasalahan ini peneliti mengembangkan media pembelajaran Android Apps berbasis Discovery Learning pada materi segiempat. Menurut Nugroho (2014) bahwa Mobile Learning adalah pembelajaran melalui perangkat teknologi nirkabel yang bisa dimanfaatkan dimana saja, dan Mobile Learning juga dapat membantu orang untuk mendapatkan pembelajaran instan hanya dengan ujung jari mereka. Hal ini senada dengan Fouzdar dan Behera (2017: 117) mengatakan bahwa Mobile Learning dapat memberikan wawasan yang benar kepada orang yang tepat kapan saja dan dimana saja hanya dengan menggunakan portable sebagai alat belajar.

Tahap design (perencanaan), pada tahap ini peneliti akan menyiapkan dan merancang perangkat dengan menyusun : silabus yang mengacu pada kurikulum K-13, RPP, merancang aplikasi android apps berbasis discovery learning, membuat lembar validasi ahli media dan materi untuk penilaian produk, soal evaluasi, kisi-kisi, kunci jawaban dan rubrik penskoran soal. Pada tahap ini peneliti menghasilkan rancangan produk dimana peneliti mendesain awal produk yang dibuat untuk penelitian. Berikut disajikan gambar tampilan dari media pembelajaran android apps berbasis discovery learning.

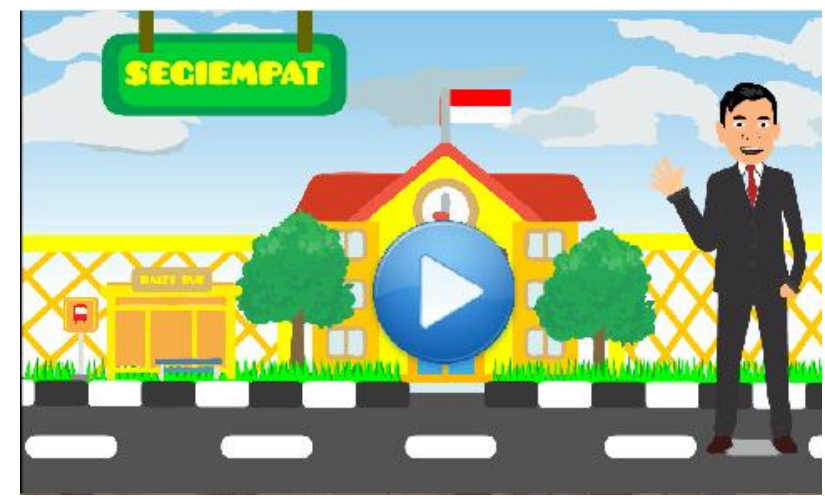

Gambar 1. Tampilan Awal 


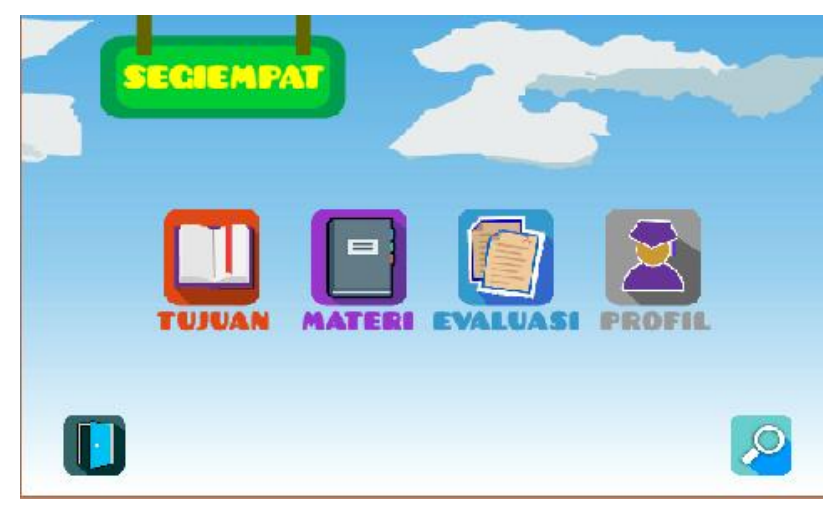

Gambar 2. Tampilan Menu Utama

Tahap development (pengembangan), hasil pengembangan aplikasi mobile learning sebagai media pembelajaran kemudian divalidasi oleh ahli media dan ahli materi. Hasil validasi selanjutnya direvisi sesuai dengan saran yang diberikan oleh masing-masing ahli. Berdasarkan hasil penilaian tersebut, ahli media yang berasal dari dosen pendidikan matematika Universitas PGRI Semarang memberikan nilai terhadap aspek yang terdapat di dalamnya sebesar $89,71 \%$ dan ahli materi yang berasal dari dosen pendidikan matematika Universitas PGRI Semarang memberikan nilai terhadap aspek yang terkandung di dalamnya yaitu sebesar $86,36 \%$. Berikut disajikan tabel skor hasil validasi ahli.

Tabel 2. Skor Hasil Validasi Perangkat Pembelajaran

\begin{tabular}{ccc}
\hline \multirow{2}{*}{ Validator } & \multicolumn{2}{c}{ Skor produk yang divalidasi } \\
\cline { 2 - 3 } & Media & Materi \\
\hline 1 & 61 & 38 \\
Presentase & $80,26 \%$ & $86,36 \%$ \\
Kriteria & baik & Sangat baik \\
\hline
\end{tabular}

Berdasarkan persentase yang diperoleh dari analisis tersebut, dapat disimpulkan bahwa media pembelajaran yang dikembangkan termasuk kategori baik menurut penilaian ahli media dan kateogri sangat baik menurut ahli materi. Selain penilaian diberikan, kedua ahli tersebut juga memberikan saran dan kritik terhadap media pembelajaran yang dibuat oleh peneliti. Media yang telah dinilai kemudian diperbaiki sesuai dengan saran tersebut. Kemudian, setelah memperbaiki produk yang sudah divalidasi oleh para ahli, peneliti menghasilkan produk yang layak dan siap digunakan untuk pembelajaran disekolah yang akan diteliti.

Kemudian, setelah memperbaiki produk yang sudah divalidasi oleh para ahli, peneliti menghasilkan produk yang layak dan siap digunakan untuk pembelajaran disekolah yang akan diteliti.

Tahap implementation (implementasi), Tahap awal penelitian ini melakukan uji coba soal terlebih dahulu sebelum diuji cobakan kepada kelas kontrol dan kelas eksperimen. Kelas uji coba dalam penelitian ini adalah kelas VII-G yang sudah mendapatkan materi segiempat. Uji coba soal dilakukan untuk mengetahui validitas, reliabilitas, daya pembeda dan taraf kesukaran dari soal uji coba tersebut. Berdasarkan hasil analisis dari soal uji coba diperoleh soal yang valid sebanyak 10 dari 14 soal uraian. Melalui perhitungan reliabiltas soal, didapatkan hasil bahwa soal uji coba reliabel dengan klasifikasi tinggi. 
Selanjutnya dalam tahap ini, peneliti sebelum mengimplementasikan atau menerapkan rancangan media yang telah dikembangkan pada situasi nyata yaitu kelas eksperimen. Berdasarkan analisis data yang diuraikan sebelumnya, peneliti melakukan analisis data awal yang dilakukan untuk mengetahui apakah kelas eksperimen dan kelas kontrol berasal dari titik tolak yang sama. Data awal diperoleh dari nilai Ujian Tengah Semester 2. Berikut disajikan tabel data analisis awal.

Tabel 3. Data Analaisis Awal

\begin{tabular}{|c|c|c|c|}
\hline \multirow{2}{*}{ Deskripsi } & \multicolumn{2}{|c|}{ Normalitas } & \multirow{2}{*}{ Homogenitas } \\
\hline & $\mathrm{E}$ & $\mathrm{K}$ & \\
\hline Data Awal & 0,0876 & 0,0779 & 2,14137 \\
\hline
\end{tabular}

Berdasarkan tabel 3, diperoleh nilai untuk uji normalitas dan uji homogenitas kelas eskperimen dan kelas kontrol. Uji normalitas data awal kelas eksperimen diperoleh nilai $L_{\text {hitung }}=0,0876<L_{\text {tabel }}=0,16176$ dan kelas kontrol diperoleh nilai $L_{\text {hitung }}=0,0779<L_{\text {tabel }}=0,16176$. Uji homogenitas kelas eksperimen dan kelas kontrol data awal diperoleh nilai $X_{\text {hitung }}^{2}=2,14137<X_{\text {tabel }}^{2}=3,841$.

Setelah mengetahui kelas eksperimen dan kelas kontrol merupakan kelas yang berdistribusi normal dan merupakan kelas yang memiliki varians yang sama atau homogen, selanjutnya melakukan uji kesamaan rata-rata atau uji t dua pihak untuk menegetahui apakah kedua kelas tersebut berasal dari rata-rata yang sama. Berikut disajikan tabel uji t dua pihak.

Tabel 4. Uji t Dua Pihak

\begin{tabular}{|c|c|c|}
\hline Aspek & $t_{\text {hitung }}$ & $t_{\text {tabel }}$ \\
\hline Hasil Belajar & $-0,5836$ & 2,301 \\
\hline tabel & 4, & diperoleh \\
\hline
\end{tabular}

$t=-0,5836 \notin D K$, jadi dapat disimpulkan bahwa bahwa rerata hasil belajar kelompok eksperimen sama dengan hasil belajar kelompok kontrol.

Selanjutnya, peneliti melakukan melakukan tes awal berupa pre test. Setelah melakukan tes awal, peneliti menerapkan media pembelajaran android apps berbasis discovery learning pada kelas eksperimen dan pembelajaran konvensional pada kelas kontrol. Pada akhir pertemuan pembelajaran masing-masing kelas, peneliti melakukan tes akhir berupa post test. Dari data yang diperoleh dilapangan kemudian dianalis akhir dengan menggunakan uji normalitas, uji homogenitas, uji N-Gain dan uji t satu pihak.

Analisis uji normalitas dan homogenitas menggunakan nilai tes akhir berupa post test. Berikut disajikan tabel data analisis akhir. 
Tabel 5. Data Analaisis Awal

\begin{tabular}{|c|c|c|c|}
\hline \multirow{2}{*}{ Deskripsi } & \multicolumn{2}{|c|}{ Normalitas } & \multirow{2}{*}{ Homogenitas } \\
\hline & $\mathrm{E}$ & $\mathrm{K}$ & \\
\hline Data Akhir & 0,1462 & 0,1569 & 0,83094 \\
\hline
\end{tabular}

Berdasarkan tabel 5, diperoleh nilai untuk uji normalitas dan uji homogenitas kelas eskperimen dan kelas kontrol. Uji normalitas data akhir kelas eksperimen diperoleh nilai $L_{\text {hitung }}=0,1462<L_{\text {tabel }}=0,16176$ dan kelas kontrol diperoleh nilai $L_{\text {hitung }}=0,1569<L_{\text {tabel }}=0,16176$. Uji homogenitas kelas eksperimen dan kelas kontrol data awal diperoleh nilai $X_{\text {hitung }}^{2}=0,83094<X_{\text {tabel }}^{2}=3,841$.

Selanjutnya peneliti melakukan uji n-gain dengan menggunakan data nilai hasil pre test dan post test pada kelas eksperimen dan kelas kontrol. Berikut disajikan tabel uji n-gain.

\begin{tabular}{ccc} 
& Tabel 6. Uji N-Gain & \\
\hline Kelas & $N-$ Kain & Kategori \\
\hline Eksperimen & 0,678 & Sedang \\
Kontrol & 0,445 & Sedang \\
\hline
\end{tabular}

Berdasarkan tabel 6, diperoleh hasil N-Gain kelas eksperimen lebih baik dari pada kelas kontrol yaitu untuk kelas eksperimen adalah 0,678 sedangkan kelas kontrol adalah 0,445. Hail ini dapat dikatakan bahwa peningkatan pemahaman konsep kelas eksperimen lebih baik dari pada kelas kontrol.

Pengujian terakhir yang dilakukan oleh peneliti adalah uji t satu pihak atau uji t pihak kanan. Uji ini bermaksud untuk mengetahui apakah hasil belajar kelas eksperimen yang menggunakan media pembelajaran android apps berbasis discovery learning lebih baik daripada kelas kontrol. Berikut disajikan tabel uji t satu pihak.

\begin{tabular}{ccc}
\multicolumn{3}{c}{ Tabel 7. Uji t Satu Pihak } \\
\hline Aspek & $t_{\text {hitung }}$ & $t_{\text {tabei }}$ \\
\hline Hasil Belajar & 6,244325155 & 1,6716 \\
\hline
\end{tabular}

Berdasarkan tabel 7, diperoleh nilai $t_{\text {hitung }} 6,244325155$ dan $t_{\text {tabel }}=1,6716$. Dimana $D K=\{t \mid t>1,6716\}$ dan $t=6,244325155 \in D K$, jadi dapat disimpulkan bahwa Pemahaman konsep matematis siswa dengan menggunakan Android Apps berbasis model Discovery Learning pada siswa kelas VII lebih baik daripada pembelajaran konvensional.

Tahap evaluation (evaluasi), merupakan tahap akhir dalam serangkaian kegiatan penelitian. Tahap evaluasi ini, setelah peneliti melakukan implementasi terhadap media yang dikembangkan. selanjutnya, media yang dikembangkan diberlakukan evaluasi terhadap siswa yang merasakan penggunaan dari media yang dikembangkan. Dalam hal ini, terdapat 10 orang siswa berasal dari 
kelas eksperimen memberikan respon tanggapannya terhadap media yang dikembangkan. berikut disajikan tabel hasil respo tanggapan siswa.

Tabel 8. Uji t Satu Pihak

\begin{tabular}{|c|c|c|c|}
\hline No & Kriteria & Jumlah Skor & Presentase \\
\hline 1 & Kualitas Isi & 102 & $85 \%$ \\
\hline 2 & Rasa Senang & 103 & $85,83 \%$ \\
\hline 3 & Motivasi & 71 & $88,75 \%$ \\
\hline 4 & Tampilan media & 107 & $89,16 \%$ \\
\hline \multirow[t]{2}{*}{5} & Praktis & 140 & $87,5 \%$ \\
\hline & Skor Total & 523 & $87,16 \%$ \\
\hline
\end{tabular}

Berdasarkan tabel 8, dapat disimpulkan dari lima aspek penilaian terhadap media pembelajaran Android Apps berbasis model Discovery Learning berdasarkan angket tanggapan dari siswa rata-rata keseluruhan sebesar $87,16 \%$ dan berada pada kriteria sangat baik sehingga media pembelajaran sudah bagus dan layak untuk digunakan oleh siswa.

Penelitian ini didukung oleh hasil dari penelitian Dwijayanti (2011) yang mengemukakan penggunaan perangkat pembelajaran matematika humanistik berbasisik konstruktivisme menggunakan ICT tergolong baik. Hasil penelitian lain oleh Nasution (2016), yang mengemukakan bahwa pembelajaran berbasis mobile learning (M-Learning) merupakan suatu pilihan baru dalam dunia belajar dan sangat efektif untuk mencapai tujuan pembelajaran. Hal ini juga sejalan dengan hasil penelian Ghozi (2014), yang menyatakan bahwa siswa merasa terbantu dan tertarik menggunakan mobile learning untuk mempelajari dan memahami materi matematika. Hasil penelitian lain yang dilakukan oleh Supandi \& Ariyanto, dkk (2018) mengemukakan bahwa Pembelajaran menggunakan Aplikasi Ponsel memberikan hasil positif pada prestasi siswa. Menurut data post-test dan pre-test dan kuesioner yang diberikan kepada siswa diperoleh peningkatan hasil tes dan sikap siswa terhadap pembelajaran matematika. Peningkatan nilai tes siswa adalah tinggi, sedangkan pengembangan sikap siswa terhadap pembelajaran masih dalam kategori sedang. Ini terjadi karena teknologi ponsel telah menjadi kebutuhan bagi siswa di setiap hari, sehingga pemanfaatannya teknologi ini masih belum mendapatkan respon yang tinggi dalam belajar matematika.

\section{KESIMPULAN}

Hasil penelitian menunjukkan bahwa: (1) Pengembangan media pembelajaran Android Apps berbasis Discovery Learning valid atau layak digunakan dalam kegiatan pembelajaran menurut ahli media, ahli materi, dan respon siswa; (2) Peningkatan pemahaman konsep matematis lebih meningkat kelas eksperimen daripada kelas kontrol dilakukan dengan cara membandingkan nilai rata-rata N-Gain setiap kelas. Nilai rata-rata N-Gain kelas eksperimen. Dari hasil perhitungan pada analisis data didapatkan nilai rata-rata N-Gain kelas eksperimen > kelas kontrol, maka dapat disimpulkan peningkatan pemahaman konsep matematis siswa yang pembelajarannya menggunakan Android Apps berbasis Discovery Learning (eksperimen) lebih meningkat daripada siswa yang mendapat pembelajaran konvensional (kontrol); (3) Berdasarkan uji coba hasil lapangan, pemahaman konsep matematis siswa dengan menggunakan Android Apps berbasis model Discovery Learning pada siswa kelas VII lebih baik daripada pembelajaran konvensional. Hal ini dapat dikatakan bahwa Pengembangan Media Pembelajaran Android Apps berbasis model Discovery Learning efektif. 


\section{DAFTAR RUJUKAN}

Ariati, L, dkk. (2016). Eksperimentasi Model Pembelajaran PBL, Jigsaw dan STAD Terhadap Pemahaman Konsep Dan Pemecahan Masalah Matematika Ditinjau Dari Adversity Quotient (AQ) Siswa. JMEE, 6(2), 106-119.

Arsyad, A. (2014). Media Pembelajaran . Jakarta: Rajawali Pres.

Behera, Foudzar. (2017). Attitude of Post Graduate Students towards Mobile Learning, Educare International Journal of education studies, 9 (2).

Dwijayanti, I. (2011). Pengembangan Perangkat Pembelajaran Matematika Humanistik Berbasis Konstruktivisme Menggunakan ICT Materi Segi Empat Kelas VII. AKSIOMA: Jurnal Matematika dan Pendidikan Matematika 2 (2).

Gharini, I. dan Khabibah, S. (2015). Pengembangan Aplikasi Mobile Learning sebagai Media Pembelajaran Matematika untuk Materi Peluang. Jurnal Pendidikan Matematika FPMIPA UNNES.

Ghozi, S. (2014). Pengembangan Materi Mobile Learning dalam Pembelajaran Matematika Kelas X SMA Perguruan Cikini Kertas Nusantara Berau. Indonesian Digital Journal of Mathematics and Education, 1(1).

Karim, A. (2011). Penerapan Model Penemuan Terbimbing dalam Pembelajaran Matematika untuk Meningkatkan Pemhaman Konsep dan Kemampuan Berpikir Kritis Siswa Sekolah Dasar. Seminar Nasional Matematika dan Terapan, 29-38.

Linuhung, N. \& Satrio, W.S. (2016). Pengaruh Pembelajaran Kooperatif Tipe Group Investigation (GI) Terhadap Kemampuan Penalaran Matematis Siswa MTs. Aksioma, 5(1), 52-60, e-ISSN 2442-5419.

Mahnun, N. (2012). Media Pembelajaran (Kajian Terhadap Langkah-langkah Pemilihan Media dan Implementasinya dalam Pembelajaran). Jurnal Pemikiran Islam, 27(2).

Mehdipour, Y. dkk. (2013). Mobile Learning for Education Benefit and Challenges. International Journal of Computation Engineering Research, 93(1).

Murizal, A, dkk. (2012). Pemahaman Konsep Matematis Dan Model pembelajaran Quantum Teaching. Jurnal Pendidikan Matematika, 1(1), 19-23.

Nasution, M. I, P. (2016). Strategi Pembelajaran Efektif Berbasis Mobile Learning Pada Sekolah Dasar. Jurnal Iqra', 1(1).

Nugroho, S. (2014). Pemanfaatan Mobile Learning GameBarisan Dan Deret Geometri Untuk Meningkatkan Minat Dan Hasil Belajar Matematika Sma Kesatrian 1 Semarang. Indonesian Digital Journal of Mathematics and Education, 1(1).

Pribadi. (2009). Model Desain Sistem Pembelajaran. Jakarta: PT Dian Rakyat.

Putra. (2013). Pengembangan Media Pembelajaran Dream Wever Model Tutorial Pada Mata Pelajaran Mengelola isi Halaman Web untuk Siswa Kelas XI Program Keahlian Multimedia di SMK Negeri 3 Singaraja. Jurnal Nasional Pendidikan Teknik Informatika (JANAPATI), 1 (2), 125-141.

$\mathrm{Su}$, C. (2012). A Mobile Gamification Learning System For Improving The Learning MotivationAnd Achievements . Journal of Computer Assisted Learning 31(2).

Sugiyono. (2014). Metode Penelitian Pendidikan Pendekatan Kuantitatif, Kualitatif, dan R\&D. Bandung: Alfabeta.

Sugiyono. (2015). Metode Penelitian \& Pengembangan (Research and Development/R\&D). Bandung: Alfabeta. 
Supandi, Ariyanto, dkk. (2018). Mobile phone application for mathematics learning. IOP Conf. Series: Journal of Physics: Conf. Series 983 (2018) 012106.

Verowita, M. (2012). Pengaruh Penerapan Model Pembelajaran Kooperatif Tipe Think Pair Share Terhadap Pemahaman Konsep DalamPembelajaran Matematika. Jurnal Pendidikan Matematika, 1 (1).

Wardhani. (2008). Anallisis SI dan SKL Mata Pelajaran Matematika SMP/MTs untuk Optimalisasi Tujuan Mata Pelajaran Matematika. Yogyakarta: Pusat Pengembangan dan Pemberdayaan Pendidik dan Tenaga Kependidikan Matematika. 